\title{
Noble gases fingerprint a metasedimentary fluid source in the Macraes orogenic gold deposit, New Zealand
}

\author{
Nicholas R. J. Goodwin ${ }^{1} \cdot$ Ray Burgess $^{1} \cdot$ Dave Craw $^{2}$ • Damon A. H. Teagle ${ }^{3}$. \\ Chris J. Ballentine ${ }^{1,4}$
}

Received: 15 September 2015 / Accepted: 7 March 2016/Published online: 23 April 2016

(C) Springer-Verlag Berlin Heidelberg 2016

\begin{abstract}
The world-class Macraes orogenic gold deposit ( $\sim 10$ Moz resource) formed during the late metamorphic uplift of a metasedimentary schist belt in southern New Zealand. Mineralising fluids, metals and metalloids were derived from within the metasedimentary host. Helium and argon extracted from fluid inclusions in sulphide mineral grains (three crush extractions from one sample) have crustal signatures, with no evidence for mantle input $(\mathrm{R} / \mathrm{Ra}=0.03)$. Xenon extracted from mineralised quartz samples provides evidence for extensive interaction between fluid and maturing organic material within the metasedimentary host rocks, with ${ }^{132} \mathrm{Xe} /{ }^{\beta 6} \mathrm{Ar}$ ratios up to 200 times greater than air. Similarly, $\mathrm{I} / \mathrm{Cl}$ ratios for fluids extracted from mineralised quartz are similar to those of brines from marine sediments that have interacted with organic matter and are ten times higher than typical magmatic/mantle
\end{abstract}

Editorial handling: B. Lehmann

Electronic supplementary material The online version of this article (doi:10.1007/s00126-016-0648-x) contains supplementary material, which is available to authorized users.

Dave Craw

dave.craw@otago.ac.nz

1 School of Earth, Atmospheric and Environmental Sciences (SEAES), The University of Manchester, Oxford Road, Manchester M13 9PL, UK

2 Geology Department, University of Otago, PO Box 56, Dunedin 9054, New Zealand

3 School of Ocean and Earth Science, Southampton Oceanography Centre, University of Southampton, European Way,

Southampton SO14 3ZH, UK

4 Present address: Department of Earth Sciences, South Parks Road, Oxford OX1 3AN, UK fluids. The Macraes mineralising fluids were compositionally variable, reflecting either mixing of two different crustal fluids in the metasedimentary pile or a single fluid type that has had varying degrees of interaction with the host metasediments. Evidence for additional input of meteoric water is equivocal, but minor meteoric incursion cannot be discounted. The Macraes deposit formed in a metasedimentary belt without associated coeval magmatism, and therefore represents a purely crustal metamorphogenic end member in a spectrum of orogenic hydrothermal processes that can include magmatic and/or mantle fluid input elsewhere in the world. There is no evidence for involvement of minor intercalated metabasic rocks in the Macraes mineralising system. Hydrothermal fluids that formed other, smaller, orogenic deposits in the same metamorphic belt have less pronounced noble gas and halogen evidence for crustal fluid-rock interaction than at Macraes, but these deposits also formed from broadly similar metamorphogenic processes.

Keywords Geochemistry · Gold · Helium · Argon · Xenon · Iodine $\cdot$ Metamorphism

\section{Introduction}

The source of fluids for formation of orogenic gold deposits has been a long-term controversial topic, fuelled by data sets from a wide variety of potential geochemical tracers (Burrows et al. 1986; de Ronde et al. 2000; Groves et al. 2003; Goldfarb et al. 2005). Various combinations of the principal components of potential mineralising fluids, magmatic, metamorphic and meteoric, have been invoked in numerous orogenic deposits (Burrows et al. 1986; Hagemann et al. 1994; Nesbitt and Muehlenbachs 1995; de Ronde et al. 2000; Goldfarb et al. 2005). Solutions to this controversy have important implications for the development of regional exploration models, 
especially if point-source magmatic fluids can be identified as important contributors to the mineralising system (Burrows et al. 1986; Goldfarb et al. 2005). Hence, this controversy has significance well beyond the confines of academic research.

A recurrent problem in interpreting the results of various geochemical tracers of fluid sources lies in fluid-rock interaction processes along the fluid pathways. These geochemical interactions almost inevitably result in at least some change in composition of the fluid away from its source composition, towards host rock characteristics. The extent of these changes depends on the reactivity of the fluid component and the relative abundance of this component in the host rock. For example, oxygen-stable isotopic ratios are notorious for rapid and largely complete changes from source signatures to rock signatures along the fluid pathways (Jenkin et al. 1994; Menzies et al. 2014). For this reason, noble gases are becoming an important research tool in deducing fluid sources because of their relatively unreactive nature in the geochemical environment (Turner et al. 1993; Ballentine et al. 2002; Kennedy et al. 2002; Kendrick et al. 2007; Fairmaid et al. 2011). In particular, noble gases can retain evidence of mantle and associated magmatic source regions despite extensive fluid mobility through crustal rocks (Mao et al. 2003; Burnard and Polya 2004; Hu et al. 2004; Graupner et al. 2006). In this study, we use noble gas contents of fluid inclusions to provide information on fluid sources and indications of potential fluid mixing along the fluid pathways.

Orogenic gold deposits occur in many metamorphic belts, and metamorphism was typically accompanied by at least some magmatism (Groves et al. 2003; Goldfarb et al. 2005). This close association between metamorphic and magmatic processes adds further complication to the problem of unravelling sources of mineralising fluids in the orogenic environment. The Otago Schist belt of southern New Zealand, in which the world-class Macraes gold deposit occurs, is relatively unusual in having no evidence for magmatism in the latter stages of metamorphism when mineralisation occurred (Mortimer 1993; Craw 2002; Pitcairn et al. 2006; Mortensen et al. 2010). The nearest coeval (Early Cretaceous) magmatism to the Macraes mineralisation system was $>200 \mathrm{~km}$ to the west (Fig. 1; Turnbull et al. 2010), and the only evidence for late tectonic magmatism in the schist belt is middle Cretaceous, $>25$ million years younger than the Macraes deposit (Tulloch et al. 2009; Mortensen et al. 2010). Hence, the Macraes deposit provides a useful amagmatic end member in the probable broad spectrum of orogenic mineralising systems. In this study, we present noble gas and associated halogen data to determine the nature of this amagmatic mineralising fluid, and we contrast this new evidence with results from several previous studies of geochemical tracers in the Macraes mineralising system.

\section{General setting}

The Macraes orogenic gold deposit occurs in lower greenschist facies metasedimentary schists on the north eastern margin of the Otago Schist belt (Figs. 1 and 2a). The Otago Schist belt formed during Mesozoic tectonic convergence on the Pacific margin of Gondwana (Mortimer 1993, 2000). In the area around the Macraes mine, the belt consists of two adjacent metasedimentary terranes, Caples and Torlesse, which were juxtaposed during Jurassic metamorphism (Fig. 1; Mortimer 1993, 2000). The exposed core of the schist belt consists of upper greenschist facies Torlesse Terrane biotite-garnet zone schists (Mortimer 2000). Underlying amphibolite facies rocks are not exposed in the Macraes area, but have been exhumed by Cenozoic uplift in the central South Island, to the north of the main Otago Schist belt (Fig. 1 inset). Protoliths for the Torlesse and Caples terranes are exposed on the belt margins and consist of lithologically monotonous turbiditic greywackes and argillites, with minor intercalations of mafic volcanic rocks (Fig. 2a). A third terrane, the Aspiring Terrane, occurs in the northwest and contains more metabasic intercalations than the other two terranes (Figs. 1 and 2d). The sediments, and the schists derived from them, show only minor compositional variations across the whole schist belt (Mortimer 1993; Pitcairn et al. 2006, 2014).

The schist belt underwent extension-related deformation and uplift in the middle Cretaceous, with development of a network of normal faults (Fig. 1; Gray and Foster 2004). These faults have been variably reactivated since then, including widespread reversal during the Cenozoic (Craw 2010). Many of the metamorphic boundaries in the schist belt are now defined by faults (Fig. 1; Mortimer 2000; Henne and Craw 2012). Miocene basaltic volcanism near the eastern coast was partially controlled by these pre-existing structures, and some of these structures are still channelling surface springs that contain detectable mantle helium emanations (Fig. 1; Hoke et al. 2000).

Mineralisation at Macraes occurred during late Jurassic to Early Cretaceous uplift of the lower greenschist facies host rocks through the brittle-ductile transition (Craw 2002; Mortensen et al. 2010). Geochemically similar, but tungsten-dominated, coeval late metamorphic mineralisation occurred at Glenorchy on the northwestern margin of the schist belt (Figs. 2d and 3; Paterson 1986; Mortensen et al. 2010). This late metamorphic (herein termed Early Cretaceous) mineralisation event was temporally and geochemically distinct from a younger, middle Cretaceous, generation of orogenic gold mineralisation (Figs. 1, 2a and 3). The middle Cretaceous generation is hosted by normal faults that are found across the whole schist belt, but gold-bearing veins are most abundant in the upper greenschist facies core (Figs. 1 and 2a). A minor 
Fig. 1 Location map for the Macraes orogenic gold deposit, and other deposits relevant to this study, in the Otago Schist belt in southern New Zealand. Summary geology of adjacent terranes is partly after Turnbull et al. 2010

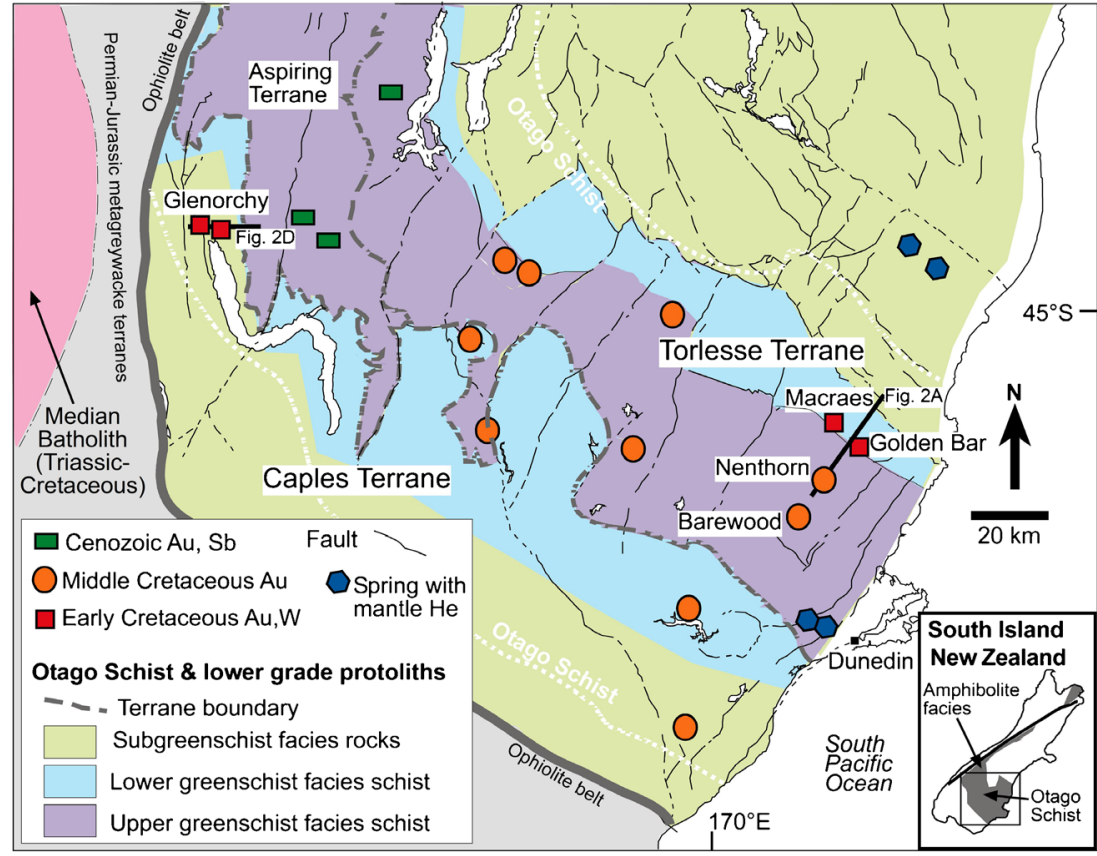

Cenozoic generation of orogenic gold mineralisation affected the northwestern part of the belt (Fig. 2d) and continues to the northeast where it is still active (Craw et al. 2006). The Early Cretaceous Glenorchy deposits were mined extensively for scheelite historically, with only minor gold production (Williams 1974) and there are no active mines. Historic gold production from the middle Cretaceous and
Cenozoic deposits was minor (Williams 1974), and no active mines occur in any of these deposits either.

\section{Mineralisation at Macraes mine}

The Macraes deposit has a total resource of $\sim 10$ million ounces $(\sim 300 \mathrm{t})$ of gold, of which $\sim 4$ million ounces have
Fig. 2 Geological setting for the samples used in this study. a Regional cross-section through the Macraes deposit and the nearby Nenthorn goldfield. b Incident light image of an auriferous pyrite porphyroblast in Macraes (Golden Bar pit) mineralised sheared schist (after Large et al. 2012). Noble gases were extracted from similar material from this locality. c $\mathrm{Au}$ and As contents of Macraes mineralised pyrite (dots) in comparison to pyrite in the host Torlesse Terrane protolith (after Large et al. 2012). d Regional cross-section through the Glenorchy area (Fig. 1), showing locations of veins sampled for this study (partly after Paterson 1986)

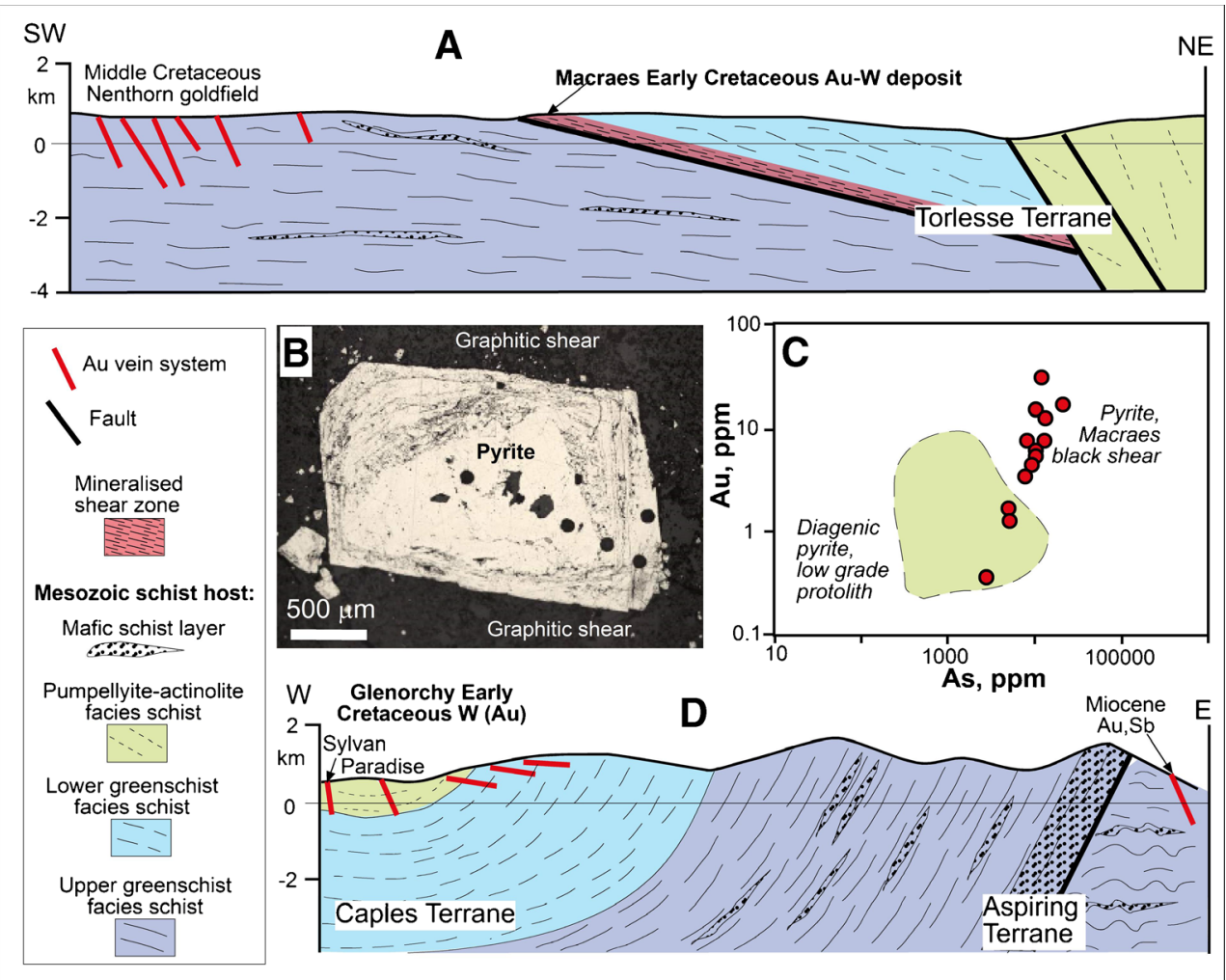




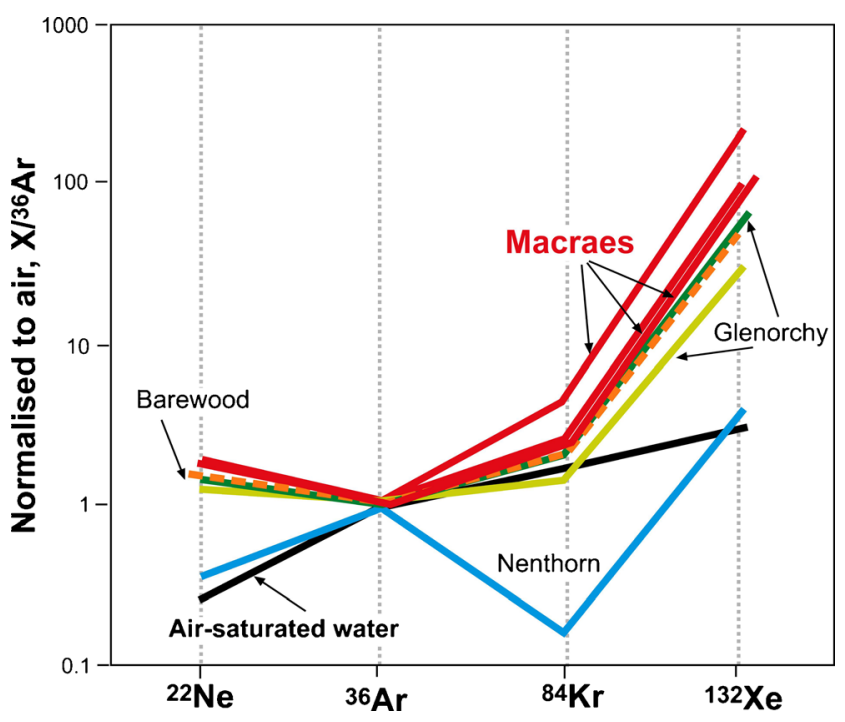

Fig. 3 Noble gas data normalised to air, $\mathrm{X} /{ }^{\beta 6}$ Ar values for fluids in quartz from Otago Schist gold deposits, in comparison to air-saturated water

been produced since modern mining began in 1990 (Moore and Doyle 2015). The deposit is hosted by a late metamorphic thrust shear zone that dips gently northeast sub-parallel to the lower greenschist facies metamorphic foliation, and is traceable along strike for $30 \mathrm{~km}$ (Fig. 2a; de Ronde et al. 2000; Craw 2002; Craw et al. 2007; Moore and Doyle 2015). The shear zone formed as the rocks were being uplifted through the brittle-ductile transition, and some of the shear fabric formed under ductile, locally mylonitic, conditions (Craw et al. 1999). The shear zone is truncated below by a middle Cretaceous normal fault, which juxtaposed the mineralised rocks against unmineralised upper greenschist facies schists (Fig. 2a).

The mineralised shear zone is up to 200-m thick, and mineralisation was focussed in and near specific shears within that shear zone, especially one shear that is designated the Hangingwall Shear in the main mining area (Craw 2002; Petrie et al. 2005). Hydrothermal alteration and associated mineralisation occurred under lower greenschist facies conditions $\left(300-400{ }^{\circ} \mathrm{C} ; 10-15-\mathrm{km}\right.$ depth; McKeag and Craw 1989; de Ronde et al. 2000; Craw 2002). Alteration was pervasive but subtle, as mineralisation and host rocks had similar mineral assemblages, and the main alteration involved transformations of accessory minerals titanite and epidote (Craw 2002). Pyrite and arsenopyrite have overgrown the shear fabric with porphyroblastic replacement textures (Fig. 2b, c), and many of the porphyroblasts were subsequently deformed by progressive shear evolution (Craw 2002; Henne and Craw 2012). Some of the more strongly deformed mineralised shears have abundant (up to $3 \mathrm{wt} \%$ ) hydrothermal graphite that accompanied sulphide porphyroblast emplacement (Craw 2002; Petrie et al. 2005; Pitcairn et al. 2005a; Craw et al. 2007; Henne and Craw 2012). Thin (typically $<1 \mathrm{~m}$ ) discontinuous quartz veins were emplaced in association with the principal mineralisation-hosting shears. Some quartz veins lie sub-parallel to the shear fabric, where they locally crosscut the shear fabric and many of these veins have been deformed and brecciated with the shear zone. Other veins cut steeply across the metamorphic foliation in the hosting schist, but are locally disrupted by shears and syn-shear folds (Craw et al. 1999; 2007). All veins were structurally coeval with each other and with the shear zone (de Ronde et al. 2000; Craw 2002). Gold is almost entirely encapsulated in sulphides in variably deformed porphyroblasts in sheared schist, and within the sulphides in both types of quartz veins (de Ronde et al. 2000; Craw 2002; Petrie et al. 2005). Both quartz vein types contain scheelite in association with the gold-bearing sulphides.

\section{Methods}

\section{Sample selection}

This study was conducted on representative mineralised material from the Macraes deposit sampled from a satellite open pit, Golden Bar, $6 \mathrm{~km}$ southeast of the main Macraes operation (Fig. 1; Large et al. 2012). Two samples of quartz were taken from a well-mineralised shear-parallel veined zone that is up to 2-m thick. One sample of sulphidic graphitic sheared schist was selected from a mineralised shear zone structurally beneath the quartz vein samples. All three samples were from fresh rock at the base of the 100-m-deep open pit. The sulphidic schist sample was obtained from the same small locality as that described by Large et al. (2012). Some of the pyrite in this sample is coarse grained $(0.5-1 \mathrm{~mm}$; cf Fig. 2b), auriferous (Fig. 2c) and variably zoned, but contains no unrecrystallised remnants of diagenetic pyrite found in lowgrade protoliths (Fig. 2b, c; Large et al. 2012). Thin quartz veinlets in the sheared schist sample were extracted from the sulphidic schist, and treated as a separate quartz subsample.

In order to provide some regional context for this study of Macraes material, two samples of Early Cretaceous quartz veins were obtained from the Glenorchy area, from the Sylvan and Paradise historic mining areas (Fig. 2d). These veins consist of massive quartz that was deposited in normal faults associated with a regional late metamorphic shear vein swarm (Paterson 1986; Begbie and Sibson 2006). In addition, two samples of quartz vein material were obtained from historic workings in middle Cretaceous gold-bearing vein systems near to Macraes, at Nenthorn and Barewood deposits (Figs. 1 and 2a; McKeag and Craw 1989; MacKenzie et al. 2006).

This study involved extraction of fluids from fluid inclusions in the above-mentioned samples. General fluid inclusion characterisation of these deposits has been done by McKeag 
and Craw 1989; Craw and Norris (1991), de Ronde et al. (2000), and MacKenzie et al. (2006). Samples were coarsely crushed $(\sim 0.5-1 \mathrm{~mm})$ so that quartz and pyrite could be handpicked with a needle under a binocular microscope. The picked separates were then cleaned by washing with de-ionised water and acetone in an ultra-sonic bath. All the quartz samples were analysed for noble gases (He, Ne, Ar, Kr, Xe) and halogens $(\mathrm{Cl}, \mathrm{Br}, \mathrm{I})$ in the fluid inclusions, and the sulphide sample was analysed for He and Ar in fluid inclusions.

Cleaned samples (0.2-0.9 g) were loaded into a stainless steel solenoid crusher (Sumino et al. 2001) connected to an all-metal, ultra-high vacuum extraction line, and were baked overnight at $125^{\circ} \mathrm{C}$ to release adsorbed atmospheric gases. Noble gases were released by crushing in vacuo and the released gases were purified by exposure to a SAES GP50 Zr$\mathrm{Al}$ alloy getter pump operated at $250^{\circ} \mathrm{C}$ and an NP10 getter pump operated at room temperature. Released purified noble gases were trapped on a cryogenic charcoal trap at $\sim 15 \mathrm{~K}$. The noble gases were sequentially released by warming the trap to determine the $\mathrm{He}$, Ne and Ar abundance and isotopic composition in turn on the University of Manchester GV5400 mass spectrometer (e.g. Sumino et al. 2001). Kr and Xe were released together and their abundance was determined at the same time. Crushing was done in at least two stages and the noble gas composition of each crush stage determined. Total yields of the individual noble gas components for each sample are reported by summing the volumes released from the crushing stages.

A reduced pressure standard of air spiked with helium $\left({ }^{3} \mathrm{He} /{ }^{4} \mathrm{He}\right.$ of $\left.14 \mathrm{R}_{\mathrm{A}}\right)$ was used to calibrate the sensitivity and isotopic mass discrimination of the system. All calibration noble gas isotopic and elemental ratios apart from He were atmospheric. Noble gas measurements were corrected for isobaric interferences, though correction of ${ }^{20} \mathrm{Ne}$ for ${ }^{40} \mathrm{Ar}^{++}$ proved difficult to resolve and as such ${ }^{20} \mathrm{Ne}$ is not reported. ${ }^{21} \mathrm{Ne}$ and ${ }^{22} \mathrm{Ne}$ are unaffected. Blank measurements were made prior to each sample analysis and corrections applied as necessary though blank values were typically $<1 \%$ for ${ }^{4} \mathrm{He}, 1 \%$ for ${ }^{21} \mathrm{Ne}, 1 \%$ for $\mathrm{Ar}, 2 \%$ for $\mathrm{Kr}$ and $2-5 \%$ for Xe. Errors are at the $1 \sigma$ level and combine statistical uncertainties on the measurement, uncertainties on the blank and isobaric interference corrections and uncertainties in mass spectrometer sensitivity and mass discrimination determined from the calibration procedure.

Noble gas (Ar, Kr, Xe) and dissolved halogen abundance was also determined in fluid inclusions from separate aliquots of cleaned quartz material together with $\mathrm{Ar}, \mathrm{Kr}$ and $\mathrm{Xe}$ abundance. The halogen determinations were performed at the University of Manchester using an extension of the $\mathrm{Ar}-\mathrm{Ar}$ technique (Bohlke and Irwin 1992a; Johnson et al. 2000). The cleaned quartz chips $(\sim 100 \mathrm{mg})$ were irradiated in the SAFARI-1 nuclear reactor, South Africa, together with hornblende neutron flux monitors to calibrate the conversion of halogens to noble gases (Johnson et al. 2000). Irradiated samples were loaded into hand crushers modified from Nupro® valves. These samples were crushed progressively, with at least three crush events performed on each sample. Released components were analysed after each crush event. Analytical procedures and subsequent data reduction were performed by methods described by Johnson et al. (2000).

\section{Results}

\section{General data set}

Because of the fluid inclusion heterogeneity within the examined samples and variable release efficiency, the absolute amounts of noble gases and halogens yielded from the analytical system are of less relevance than the elemental ratios, so only ratios are quoted herein. A summary of the analytical results for $\mathrm{He}$ and Ar extraction from the Macraes pyrite sample is presented in Table 1. Noble gas contents of fluid inclusions extracted from all the quartz samples are summarised in Supplementary Table 1. Halogen and Ar contents of fluid inclusions extracted from irradiated samples of quartz are summarised in Supplementary Table 2. Data relevant to deduction of mineralising fluid source(s) are plotted in Figs. 3, 4, 5, 6 and 7 . The plotted data include the total values for evolved fluids derived from up to three crush events during analysis, and these are indicated with black dots in each graph. Variations in compositions between different crush events, compared to the total analyses, give an indication of the variability of the fluid inclusion populations and may reflect differential extraction of fluids from different generations of fluid entrapment. In particular, the generally lower ${ }^{40} \mathrm{Ar} /{ }^{36} \mathrm{Ar}$ in first crush aliquots (as in Supplementary Table 2) has been attributed to early loss of air-containing secondary inclusions ( $\mathrm{Hu}$ et al. 2009).

Representative normalised noble gas data for each quartz sample are presented in Fig. 3 in comparison to air-saturated water values. This plot clearly shows that there are major deviations of the extracted noble gas compositions from airsaturated water compositions and these were different from air. The Nenthorn sample shows considerable deviation from both air-saturated water and the patterns described by the other samples, especially for $\mathrm{Kr}$ (Fig. 3). Assuming the Nenthorn sample results do not reflect unique analytical problems, these results are indicative of a distinctly different fluid. Since the Nenthorn deposit is only marginally relevant to the present study, we persist in using the data on subsequent plots for comparison only and do not draw any significant conclusions using this part of the data set. 
Table 1 Helium and argon data for fluids extracted from Macraes sulphides. Absolute values are cubic centimetre STP per gramme sample. ${ }^{40} \mathrm{Ar} *$ is ${ }^{40} \mathrm{Ar}$ corrected for atmospheric contribution

\begin{tabular}{llclllrl}
\hline & ${ }^{3} \mathrm{He}\left(\times 10^{-14}\right)$ & ${ }^{4} \mathrm{He}\left(\times 10^{-14}\right)$ & $\mathrm{R} / \mathrm{Ra}$ & ${ }^{40} \mathrm{Ar}\left(\times 10^{-7}\right)$ & ${ }^{36} \mathrm{Ar}\left(\times 10^{-10}\right)$ & ${ }^{40} \mathrm{Ar} /{ }^{36} \mathrm{Ar}$ & ${ }^{40} \mathrm{Ar} * /{ }^{4} \mathrm{He}$ \\
\hline Crush 1 & 2.19 & 46.08 & 0.034 & 4.04 & 11.49 & 352 & 0.140 \\
$1 \sigma$ & 0.64 & 0.08 & 0.010 & 0.01 & 0.10 & 3 & 0.007 \\
Crush 2 & 2.13 & 35.74 & 0.043 & 2.22 & 5.78 & 385 & 0.144 \\
$1 \sigma$ & 0.53 & 0.06 & 0.011 & 0.01 & 0.05 & 4 & 0.005 \\
Crush 3 & 1.89 & 64.03 & 0.021 & 3.01 & 5.59 & 539 & 0.213 \\
$1 \sigma$ & 0.64 & 0.20 & 0.007 & 0.01 & 0.05 & 5 & 0.003 \\
Total & 6.20 & 145.85 & 0.030 & 9.28 & 22.86 & 406 & 0.173 \\
$1 \sigma$ & 1.05 & 0.28 & 0.005 & 0.02 & 0.12 & 3 & 0.003 \\
\hline
\end{tabular}

\section{Helium data from quartz and sulphides}

The He contents of all quartz samples were very low and ${ }^{3} \mathrm{He}$ was not detected in any quartz samples. He is readily lost by diffusion from fluid inclusions in quartz (Kendrick et al. 2001), and this is assumed to be the case for the Macraes samples (Fig. 4a). Sulphide minerals retain He more
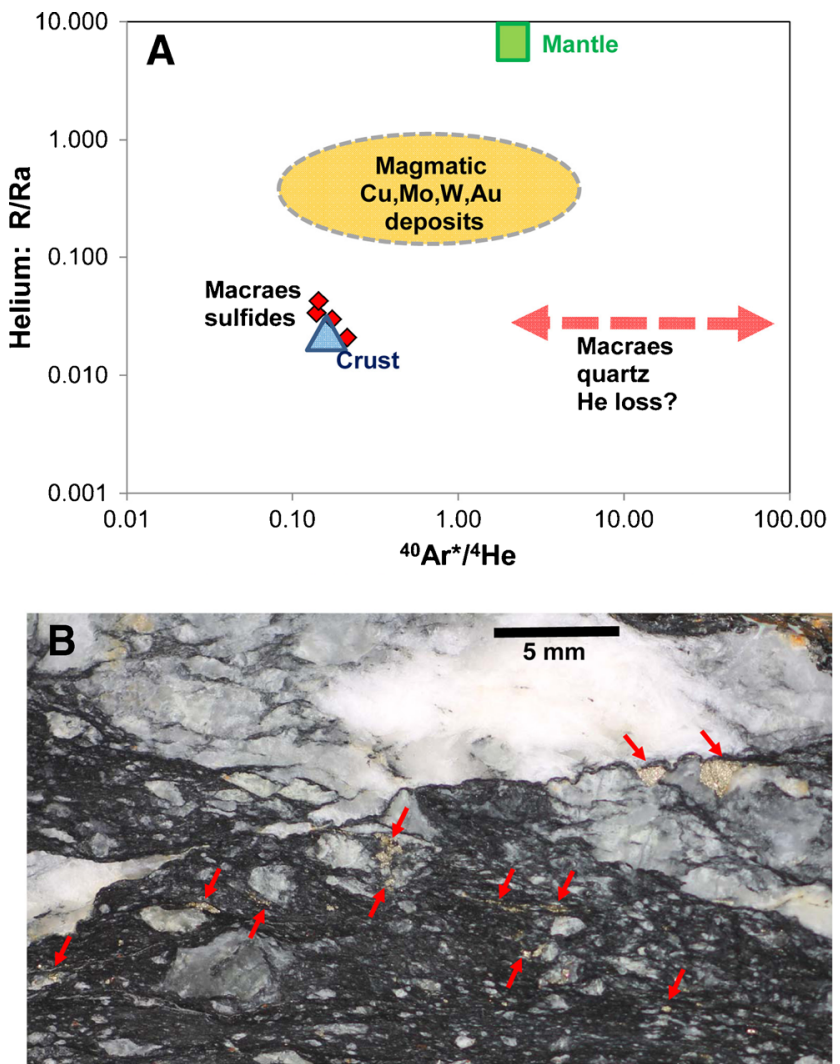

Fig. 4 Helium from the Macraes sulphide sample. a He and ${ }^{40} \mathrm{Ar} *$ (corrected for atmospheric contribution) data for Macraes sulphide sample, in comparison to typical crustal, magmatic and mantle reservoirs (Ballentine et al. 2002; Ozima and Podosek 2002). Magmatic field is summarised from Stuart et al. (1995), Kendrick et al. (2001), and $\mathrm{Hu}$ et al. $(2004,2012)$. b Photograph of a portion of the sample from which the He was extracted from a sulphide separate, showing the shearrelated textures of sulphides (arrowed), predominantly along synmineralisation shears and veinlets effectively than quartz (Stuart et al. 1995; Hu et al. 2009; 2012), so sulphide mineral crush data provide a better reflection of the He content of the Macraes mineralising fluid. The gases were extracted from the single Macraes sulphide sample in this study with three crush stages (Table 1). He was detected in all crush aliquots of the Macraes sulphide sample, and ${ }^{3} \mathrm{He} /{ }^{4} \mathrm{He}$ ratio was $\sim 0.03 \mathrm{Ra}$ (Fig. $4 \mathrm{a}$ ).

The sulphide separate from this sample was dominated by pyrite that was disseminated through sheared rock, principally along the shear fabric (Fig. 4b). These sulphide grains have locally overgrown the syn-mineralisation shear fabric via replacement reactions to form porphyroblasts (Fig. 2; Craw 2002; Henne and Craw 2012). Some pyrite also occurs in thin syn-mineralisation quartz veinlets that locally cut shear fabric but have been deformed by shearing as well (Fig. 4b). Hence, the pyrite grains were entirely derived from the late metamorphic mineralisation process, and the contained noble gases reflect the composition of the mineralising fluid.

\section{Other noble gas data}

The ${ }^{40} \mathrm{Ar} /{ }^{36} \mathrm{Ar}$ values for the Macraes quartz and sulphide samples show a broad range, $>700$, with the sulphide

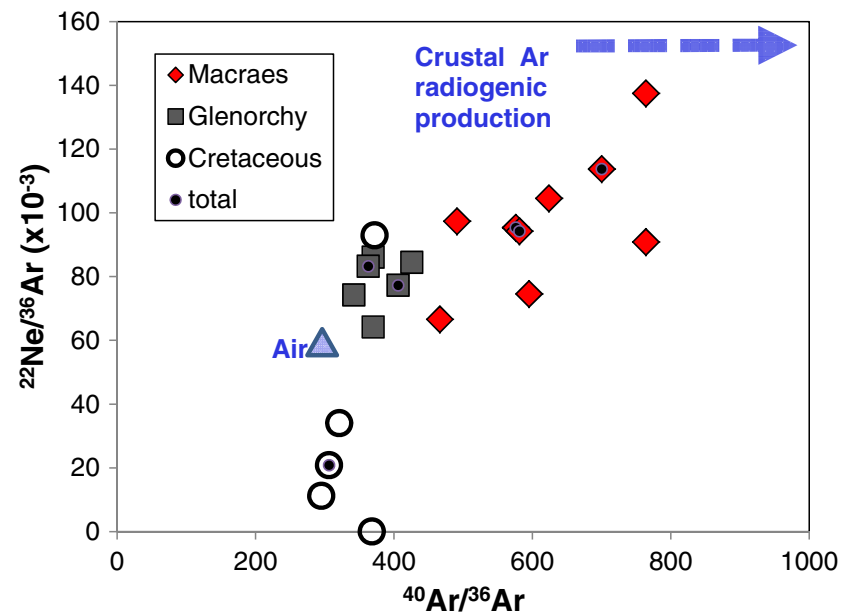

Fig. 5 Neon and argon data for Macraes and other Otago Schist samples, compared to air and crustal generation (Ballentine et al. 2002; Kennedy et al. 2002; Ozima and Podosek 2002) 

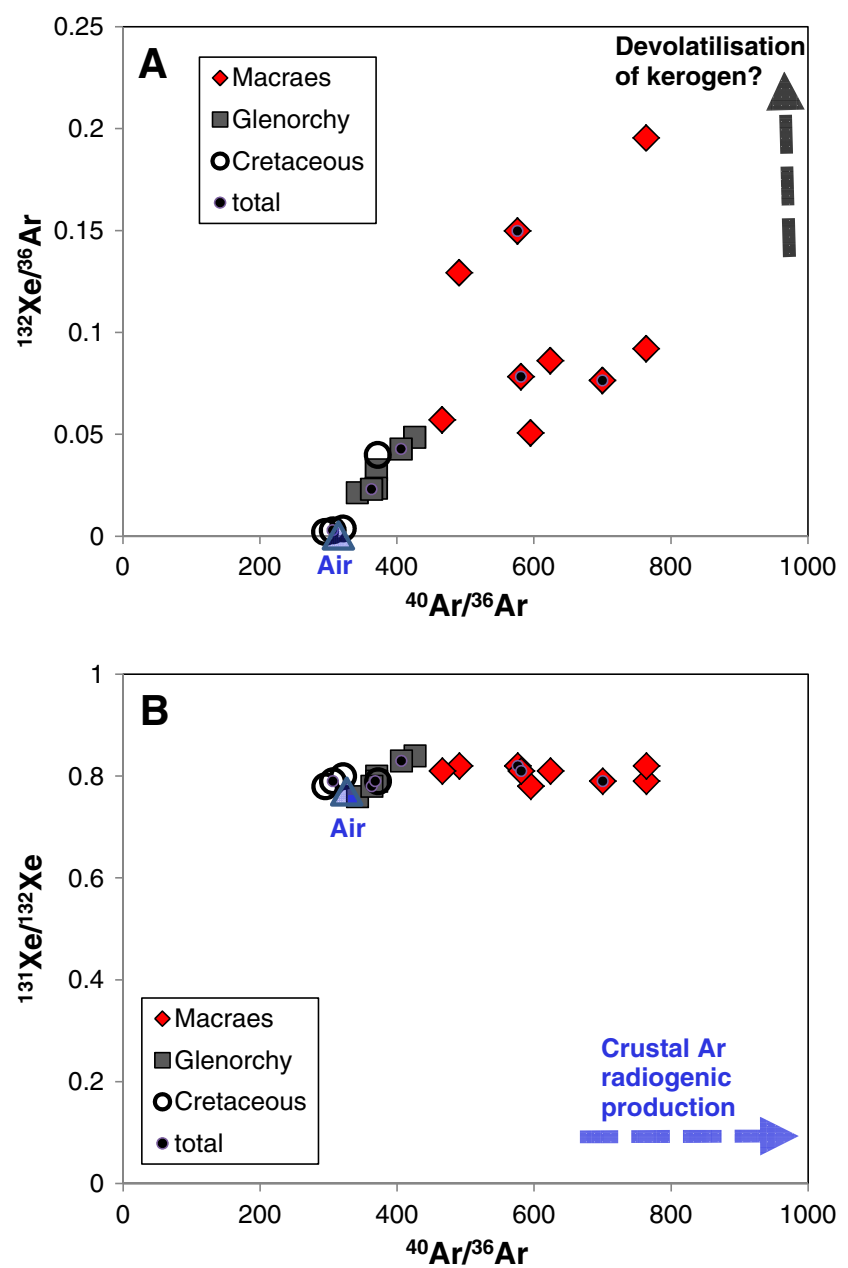

Fig. 6 Xenon and argon data for Macraes and other Otago Schist samples, in relation to air and crustal reservoirs (see text for references)

sample having generally lower values, down to as low as 352 (Table 1; Supplementary Table 1). Glenorchy and middle Cretaceous quartz samples have even lower ${ }^{40} \mathrm{Ar} /{ }^{36} \mathrm{Ar}$ values of 300-400, little different from air (Fig. 5). The higher ${ }^{40} \mathrm{Ar} /{ }^{36} \mathrm{Ar}$ values at Macraes reflect a greater radiogenic ${ }^{40} \mathrm{Ar}$ component that is derived from crustal radioactive decay. The ${ }^{40} \mathrm{Ar} *$ content, the ${ }^{40} \mathrm{Ar}$ content corrected for atmospheric contribution based on the ${ }^{36} \mathrm{Ar}$ analyses, yields ${ }^{40} \mathrm{Ar} * /{ }^{4} \mathrm{He}$ ratios in the Macraes sulphide sample of 0.14-0.2, which are typical crustal values (Fig. 4). Presumed He loss from Macraes quartz samples has resulted in elevated values, up to $\sim 100$, for ${ }^{40} \mathrm{Ar} * /{ }^{4} \mathrm{He}$, and the sulphide values of this ratio better reflect the crustdominated composition of the mineralising fluid than do the quartz values (Fig. 4).

The ${ }^{22} \mathrm{Ne} /{ }^{36} \mathrm{Ar}$ values for the Macraes deposit are generally close to air values with minor spread to higher values of ${ }^{22} \mathrm{Ne} /{ }^{36} \mathrm{Ar}$ than most of the other comparative deposits (Fig. 5). The Macraes air-normalised ${ }^{84} \mathrm{Kr} /{ }^{36} \mathrm{Ar}$ ratios of $1-$ 2 are between values of air and air-saturated water (Fig. 3;
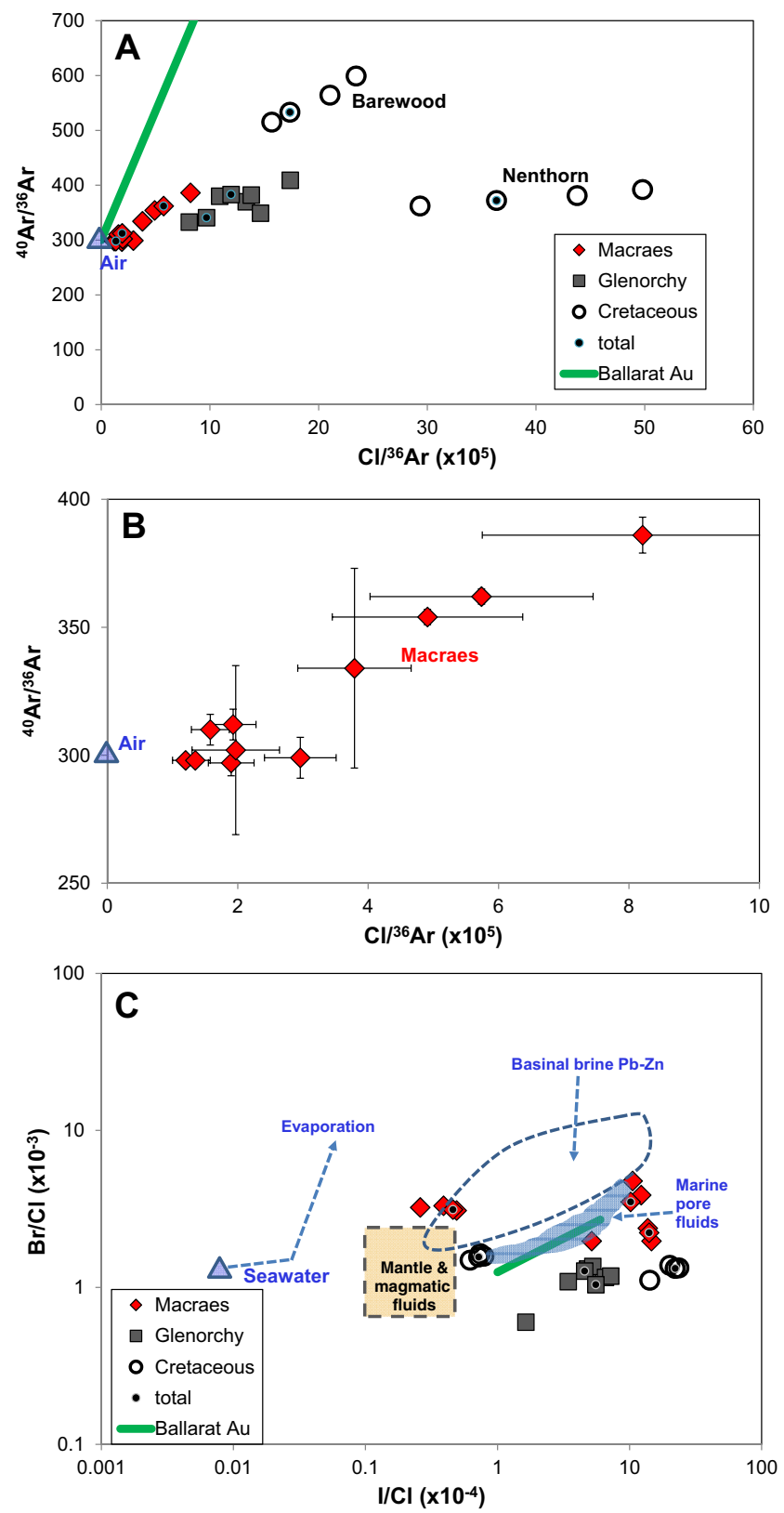

Fig. 7 Halogen and argon ratios for Macraes and other Otago Schist gold deposits. Data trends for the Ballarat orogenic goldfield, Australia (Fairmaid et al. 2011) are indicated for comparison. a Chlorine and ${ }^{40} \mathrm{Ar}$ data. b Macraes chlorine and ${ }^{40} \mathrm{Ar}$ data (from a), with expanded scales and $1 \sigma$ uncertainties. $\mathbf{c} / / \mathrm{Cl}$ versus $\mathrm{Br} / \mathrm{Cl}$ ratios in comparison to crust and mantle reservoirs (after Bohlke and Irwin 1992b; Kendrick et al. 2001; Muramatsu et al. 2007; Fairmaid et al. 2011)

Ozima and Podosek 2002). Xenon data for Macraes show distinct elevation of ${ }^{132} \mathrm{Xe}$ compared to air, to a much greater extent than the other deposits, and the Macraes data are highly variable (Fig. 6a). However, the ${ }^{131} \mathrm{Xe} /{ }^{132} \mathrm{Xe}$ ratios of Macraes fluids are air-like, and show little variation internally, or in comparison to the other Otago Schist deposits (Fig. 6b). 


\section{Halogen data}

Previous work has shown that fluid inclusions at Macraes are two-phase water and have variable salinity, ranging from 0.2 to $3.2 \mathrm{wt} \% \mathrm{NaCl}$ equivalent, but with most data near $1 \mathrm{wt} \%$ $\mathrm{NaCl}$ equivalent (McKeag and Craw 1989; de Ronde et al. 2000). Only traces of $\mathrm{CO}_{2}$ occur in these inclusions $(0.1-$ $0.8 \mathrm{~mol} \%$; de Ronde et al. 2000). Importantly, de Ronde et al. (2000) showed that the salinity variations at Macraes occur in primary fluid inclusions directly associated with goldtungsten mineralisation, rather than reflecting a component of more dilute secondary inclusions trapped in the veins during uplift. Glenorchy mineralising fluids were low salinity water, near $0.4 \mathrm{wt} \% \mathrm{NaCl}$ equivalent (Craw and Norris 1991). The Early Cretaceous mineralising fluids had generally lower salinities than two-phase water inclusions in the middle Cretaceous deposits, which typically range from $>3$ (Barewood) to as high as 8 (Nenthorn) wt\% $\mathrm{NaCl}$ equivalent (McKeag and Craw 1989; MacKenzie et al. 2006). Some Nenthorn fluid inclusions contain three phases, with $\mathrm{CO}_{2}$ as a major component, reflecting fluid immiscibility during entrapment (McKeag and Craw 1989). This complicating factor in the fluid inclusion paragenesis at Nenthorn may have contributed to the anomalous noble gas elemental ratios observed in the quartz sample (Fig. 3).

The generally lower salinities of Early Cretaceous mineralising fluids compared to middle Cretaceous deposits are reflected in the present data set, as the Early Cretaceous deposits have lower $\mathrm{Cl} /{ }^{36} \mathrm{Ar}$ (Fig. 7a; Supplementary Table 2). Data from all deposits show broadly linear arrays in Fig. 7a, but the gradients and ranges of these arrays are all different. The Macraes data have a similar gradient to the Barewood data, but smaller range (Fig. 7a, b). All these linear arrays project to intersect the ${ }^{40} \mathrm{Ar} /{ }^{36} \mathrm{Ar}$ axis near to the air value (Fig. 7a, b). Macraes fluids have a wide range of $\mathrm{I} / \mathrm{Cl}$ ratios that are distinctly different from seawater but overlap with typical marine sedimentary pore fluids and show some minor overlap with mantle compositions (Fig. 7c). The Macraes Br/ $\mathrm{Cl}$ ratios are within a narrow range, but also similar to those of marine pore fluids (Fig. 7c). These Macraes $\mathrm{Br} / \mathrm{Cl}$ ratios are higher than those of all of the other comparative Otago Schist deposits and higher than that of seawater (Fig. 7c).

\section{Discussion}

\section{No magmatic or mantle component}

Fluid inclusions in mantle xenoliths entrained in Miocene alkaline volcanos in the Macraes area have ${ }^{3} \mathrm{He} /{ }^{4} \mathrm{He}$ ratios of $7-$ $11 \mathrm{Ra}$ (Fig. 4; Hoke et al. 2000). Hence, the very low ${ }^{3} \mathrm{He} /{ }^{4} \mathrm{He}$ ratios derived from the Macraes sulphide sample $(\mathrm{R} / \mathrm{Ra} \sim 0.03$; Fig. 4, Table 1) suggest that there was essentially no mantle helium component in the mineralising fluid. Some modern surface springs have $\mathrm{R} / \mathrm{Ra}$ as high as 7 , reflecting ongoing mantle helium passage to the surface (Hoke et al. 2000). The extensional structures that control those springs were initiated in the middle Cretaceous at the earliest, and the Macraes data suggest that prior to that extensional event, there was negligible mantle He passing into the Otago Schist belt. Halogen data from Macraes show a broad range that overlaps mantle compositions, but also overlaps marine sediments and associated $\mathrm{Pb}-\mathrm{Zn}$ deposits (Fig. 7c).

Noble gas data from many mineral deposits around the world indicate at least some incorporation of mantle-derived helium in the mineralising systems (Stuart et al. 1995; Burnard et al. 1999; Mao et al. 2003; Hu et al. 2004; Graupner et al. 2006). The exact role of this fluid component in the mineralising systems is not known, but its presence is commonly indicative of a magmatic input (Kendrick et al. 2001; Burnard and Polya 2004; Graupner et al. 2006). Magmatichydrothermal mineral deposits, such as porphyry $\mathrm{Cu}-\mathrm{Mo}$ and skarn systems, commonly have ${ }^{3} \mathrm{He} /{ }^{4} \mathrm{He}$ of $0.5-2 \mathrm{Ra}$ (Fig. 4; Stuart et al. 1995; Kendrick et al. 2001; Burnard and Polya 2004; $\mathrm{Hu}$ et al. 2004). Intrusion-related gold mineralisation can also have mantle He contributions that typically range from minor (0.2-0.4 Ra; Hu et al. 2004; Graupner et al. 2006) to major (2-5 Ra; Mao et al. 2003).

Some orogenic gold deposits around the world also have evidence of mantle-derived helium that may be indicative of a magmatic component to the mineralising fluid (Burnard et al. 1999; Graupner et al. 2006; Li et al. 2007, 2012). The mantle ${ }^{3} \mathrm{He} /{ }^{4} \mathrm{He}$ signals in these orogenic deposits can range from subtle ( $<0.5 \mathrm{Ra}$; Graupner et al. 2006; Li et al. 2007) to moderate (1 to 1.5 Ra; Sun et al. 2009; Li et al. 2012), and these can overlap the mantle helium signals for fully magmatic systems. Mantle fluids associated with lamprophyric dykes coeval with mineralisation may have accompanied, and contributed, to gold emplacement in some of these systems (Graupner et al. 2006; Sun et al. 2009).

The Macraes deposit is distinctly different from the abovedescribed systems, in having no evidence from noble gas data for mantle or magmatic involvement in mineralisation. This supports geological observations that there was no coeval magmatism during Early Cretaceous mineralisation in the Otago Schist belt. The nearest late Jurassic-Early Cretaceous magma bodies to Macraes, in the Median Batholith, are now $>200 \mathrm{~km}$ away, and were even farther away prior to Cenozoic shortening in parts of the intervening schist belt (Figs. 1 and 2d; Craw et al. 2006; Turnbull et al. 2010). In addition, the Median Batholith is separated from the Otago Schist belt by two Permian-Jurassic metagreywacke terranes and an ophiolite belt, none of which include Jurassic-Early Cretaceous intrusive rocks (Fig. 1). These terranes have been deformed and thinned during Cenozoic tectonism, and separation of the Otago Schist belt from magmatic rocks to the 
west was greater in pre-Cenozoic time. Further, magmatic activity in the Median Batholith was relatively quiescent in the Jurassic and Early Cretaceous (Turnbull et al. 2010). Some remnants of silicic eruptive volcanic deposits occur in late orogenic sediments that rest unconformably on the Otago Schist belt near to Macraes, but these are middle Cretaceous in age ( 112 Ma; Tulloch et al. 2009), substantially younger than the Macraes mineralisation (135-140 Ma). Even lamprophyre dykes, commonly coevally associated with orogenic gold deposits elsewhere (earlier), are absent from the Macraes deposit, although this association does occur with the Miocene stage of mineralisation in west of the Otago Schist belt (Fig. 2d; Craw et al. 2006).

\section{Crustal fluid signature}

The strong crustal helium and argon signature of Macraes mineralising fluid (Fig. 4) is supported by the overlap between Macraes halogen data and that of fluids in marine sediments (Fig. 7c). In particular, the relatively high $\mathrm{I} / \mathrm{Cl}$ ratio of some Macraes fluids is indicative of interaction with organic shales and preferential incorporation of iodine released from maturation of kerogen (Muramatsu and Wedepohl 1998; Muramatsu et al. 2007; Fairmaid et al. 2011). Bromine has been enriched in Macraes fluids compared to the other Otago Schist gold deposits, and this $\mathrm{Br}$ may have been derived from the same processes of interaction with organic shales (Muramatsu and Wedepohl 1998; Muramatsu et al. 2007). Likewise, the trend towards elevated ${ }^{132} \mathrm{Xe} /{ }^{36} \mathrm{Ar}$ of Macraes fluids may be indicative of incorporation of xenon from maturing kerogen in organic sediments (Torgersen and Kennedy 1999; Zhou et al. 2005; Fairmaid et al. 2011). The Torlesse Terrane protoliths, especially the argillites, of the host rocks in the Macraes area (Fig. 1) contain minor but widespread detrital organic material which becomes progressively mature with increasing metamorphic grade (Pitcairn et al. 2005a; Henne and Craw 2012). Hence, fluids interacting with these host rocks within the metamorphic pile have apparently inherited noble gas and halogen characteristics from the sedimentary protolith that have subsequently been preserved in the Macraes deposit.

The general trend of increasing sedimentary ${ }^{132} \mathrm{Xe}$ with increasing crustal radiogenic ${ }^{40} \mathrm{Ar}$ (Fig. 7a) suggests an end member fluid commonly enriched in both noble gas components. Such a fluid could be the product of metamorphic devolatilisation of the host schist, liberating Xe adsorbed in kerogen, and ${ }^{40} \mathrm{Ar}$ accumulated from $\mathrm{K}$ decay in feldspars. However, the ${ }^{40} \mathrm{Ar} /{ }^{36} \mathrm{Ar}$ data are overall lower in comparison to similar deposits elsewhere in the world (Fairmaid et al. 2011; Graupner et al. 2006) and in comparison to recent mineralisation in the Alpine Schist to the northeast. This could reflect the relatively juvenile age of the Otago host rocks at the time of mineralisation.
A notable feature of the Macraes fluids is the range of compositions that occurs in the mineralised rocks. Salinity determinations by de Ronde et al. (2000) have shown that fluid compositional variability is a feature of the mineralising system, not an artefact of mixed fluid inclusion generations. Hence, we interpret the observed variations of the ${ }^{40} \mathrm{Ar} /{ }^{36} \mathrm{Ar}$ (Figs. 5 and $6 \mathrm{~b}$ ), ${ }^{132} \mathrm{Xe} /{ }^{36} \mathrm{Ar}$ (Fig. 6a) and halogen ratios (Fig. $7 \mathrm{a}-\mathrm{c}$ ) to reflect variability in the mineralising fluid. Well-defined linear compositional trends with respect to halogens and radiogenic argon have been reported for the Ballarat orogenic goldfield of Australia (Fig. 7a, c; Fairmaid et al. 2011). These trends have been interpreted as reflecting either mixing of two end member crustal fluids during mineralisation, or variable interaction of a single crustal fluid with organic shales (Fairmaid et al. 2011). These Ballarat goldfield trends are similar to, but better defined than, those observed at Macraes and also those observed for the other Otago Schist deposits in this study (Fig. 7a-c). Hence, while the Macraes data could be interpreted as fluid mixing during mineralisation, as suggested for one alternative at Ballarat (Fairmaid et al. 2011), the more irregular Macraes data ranges suggest an interpretation involving a single fluid with variable crustal rock interaction. However, these alternatives are not clearly distinguishable with the current data set.

The ${ }^{21} \mathrm{Ne} /{ }^{22} \mathrm{Ne}$, air-normalised ${ }^{84} \mathrm{Kr} /{ }^{36} \mathrm{Ar}$ and ${ }^{131} \mathrm{Xe} /{ }^{132} \mathrm{Xe}$ data for Macraes fluids all have values near to air or airsaturated water (Figs. 3, 5 and 6b). These data can be interpreted as evidence for involvement of meteoric water in the Macraes mineralising system but some consideration of the sources of atmosphere-derived noble gases in the subsurface is required. In aquifers and low temperature systems, the dominant source of air-derived noble gases in water is equilibration of the water with the atmosphere before entering the subsurface (ASW). Our understanding of the processes controlling the ASW noble gas concentrations are well enough understood that for example, the data can be inverted for recharge temperature that can be robustly determined to better than $\pm 0.5^{\circ} \mathrm{C}$ (e.g. Ballentine and Hall 1999). This is routinely used as a palaeoclimate tool. As fluids interact with sediments, atmosphere-derived noble gases that are trapped in the sediments can be observed entering the fluid phase. Atmospherederived $\mathrm{Kr}$ and $\mathrm{Xe}$, for example, are preferentially adsorbed within carbonaceous-rich sediments and, if hydrocarbon prone, are released into the ambient fluid system during hydrocarbon generation (Torgersen and Kennedy 1999; Zhou et al. 2005). Any changes in relative atmosphere-derived ${ }^{36} \mathrm{Ar} /{ }^{20} \mathrm{Ne}$ in these systems can be accounted for with multiphase processes (Battani et al. 2000; Zhou et al. 2005).

Atmosphere-derived ${ }^{36} \mathrm{Ar}$ and ${ }^{20} \mathrm{Ne}$ are nevertheless found at some level within minerals and it has been proposed that fluid-rock interaction in mineralising systems can release significant amounts into the water phase when the water/rock ratio is very low, with some single-phase water systems 
containing more ${ }^{36} \mathrm{Ar}$ and ${ }^{20} \mathrm{Ne}$ than can be accounted for by ASW (Kendrick et al. 2002, 2007). Kendrick et al. (2007) suggest that prograde fluids formed by dehydration of crystalline basement are likely to have high ${ }^{40} \mathrm{Ar} /{ }^{36} \mathrm{Ar}(>10,000)$, low

${ }^{36} \mathrm{Ar}$ concentrations and low salinity. Dehydration of sedimentary material in contrast is predicted to produce a fluid with relatively higher ${ }^{36} \mathrm{Ar}$ concentrations and lower ${ }^{40} \mathrm{Ar} /{ }^{36} \mathrm{Ar}$ $(<2000)$, but still containing a clear and resolvable radiogenic ${ }^{40} \mathrm{Ar}$ excess, ${ }^{40} \mathrm{Ar} *$, compared with the air ratio of ${ }^{40} \mathrm{Ar} /{ }^{36} \mathrm{Ar}=295.5$.

In this context, we can interpret the two components mixing in ${ }^{40} \mathrm{Ar} /{ }^{36} \mathrm{Ar}$ and $\mathrm{Cl} /{ }^{36} \mathrm{Ar}$ space that is apparent in all samples analysed (Fig. 7a, b). One end member has a high ${ }^{40} \mathrm{Ar} /{ }^{36} \mathrm{Ar}$ component and some degree of salinity. The good correlation of excess xenon (high ${ }^{131} \mathrm{Xe} /{ }^{36} \mathrm{Ar}$ ) with ${ }^{40} \mathrm{Ar} /{ }^{36} \mathrm{Ar}$ (Fig. 6) and local context provides strong evidence that this component is derived from the sedimentary source, and likely supplies the nascent fluid. The other end member, with air-like ${ }^{40} \mathrm{Ar} /{ }^{36} \mathrm{Ar}$, has no radiogenic ${ }^{40} \mathrm{Ar} *$. This cannot be derived from the sedimentary or crystalline rock system. This can only be either ubiquitous air contamination of all samples or an intrinsic fresh meteoric water component. Samples here have been prepared, cleaned and baked at $125^{\circ} \mathrm{C}$ in a hard vacuum for at least $12 \mathrm{~h}$. Noble gas volumes released are relatively high and any remaining air contaminant is likely to be small. While it is never possible to rule out some degree of air contamination, we think this unlikely to be significant and argue that the low salinity and low ${ }^{40} \mathrm{Ar} /{ }^{36} \mathrm{Ar}$ component is the signal of an intrinsic fresh meteoric water component within the samples that is heterogeneous at the fluid inclusion scale.

\section{Comparison to other tracers}

The Macraes noble gas data provide strong evidence for a dominantly crustal fluid source, with extensive fluid-rock interaction between fluid(s) and the host metasedimentary schists. The noble gas data essentially preclude involvement of a magmatic fluid component, in accord with the geological evidence. The crustal fluid flow system occurred during the latter stages of metamorphism in the Otago Schist belt, and were apparently linked to this metamorphism on a regional scale in order to interact with the rock and transfer $>10$ million ounces of gold, and related metals, into a narrow structural zone. The key discriminating noble gas tracer data for this process are summarised in Fig. 8, and these results are compared to other available data that are on the Macraes deposit relevant to the origin of fluids and metals, and formation of the deposit. The helium and argon data confirm the crustal, rather than magmatic fluid source, and the neon data also preclude a magmatic source. The xenon and iodine data reflect the extensive fluid interaction with argillaceous metasediments containing maturing organic matter.
Relatively low $\delta \mathrm{D}$ isotope composition of Macraes fluid inclusions has been interpreted to indicate a meteoric fluid end member in a mixed fluid mineralising system (de Ronde et al. 2000). As with the noble gas data (earlier), this interpretation cannot be discounted. A recent study has demonstrated that meteoric fluids can penetrate below the brittle-ductile transition while still retaining a strong depleted deuterium signal (Menzies et al. 2014). However, similar low $\delta \mathrm{D}$ values could also result from interaction with hydrocarbons, especially methane, related to maturation of organic matter in the host rocks (Craw 2002). The xenon and iodine data from this study support this interpretation, as do the carbon isotopes, which reflect varying degrees of equilibration with graphite. The Macraes deuterium data also appear to have a relatively enriched end member that could be interpreted as of magmatic origin (de Ronde et al. 2000). However, this enriched deuterium may also reflect a schist host rock signature resulting from host rock interaction or metamorphogenic derivation, as do the associated oxygen isotopic data. This latter interpretation is more likely since noble gas data and geological observations do not support magmatic involvement. Macraes mineralised rock nitrogen and sulphur isotopic ratios are essentially identical to those of the host rock metasedimentary rocks, reflecting the extensive fluid-rock interaction that the noble gas data have indicated.

Lead isotope ratios at Macraes are the same as those of host metasedimentary rocks, with no detectable input from the mafic schists that are intercalated with the metasedimentary schists (Figs. 2a, d and 8). These data imply that at least some of the metals for the mineralisation process were derived from the host rocks (Mortensen et al. 2010). Similarly, gold and arsenic contents of the underlying amphibolite facies metasedimentary schists are distinctly lower than their low-grade protoliths, implying that there was regional scale metal and metalloid depletion beneath Macraes during metamorphism (Pitcairn et al. 2006, 2014). The source of the gold and arsenic may lie in diagenetic pyrite in the low-grade protoliths (Fig. 2c; Large et al. 2012). The extensive interaction between fluid and rock in the metamorphic pile that was required to facilitate these mobilisation processes is confirmed by the noble gas and halogen data in this study. Similar metamorphogenic tungsten mobilisation occurred, albeit initially at lower metamorphic grade than the Macraes host rocks (Pitcairn et al. 2014). The processes of concentration of tungsten into the Macraes deposit are therefore more complex than for gold and arsenic, and presumably involve progressive geochemical recycling. However, neodymium isotopic data on the resultant Macraes scheelite confirms this crustal source and precludes involvement of magmas of the Median Batholith (Farmer et al. 2012). 


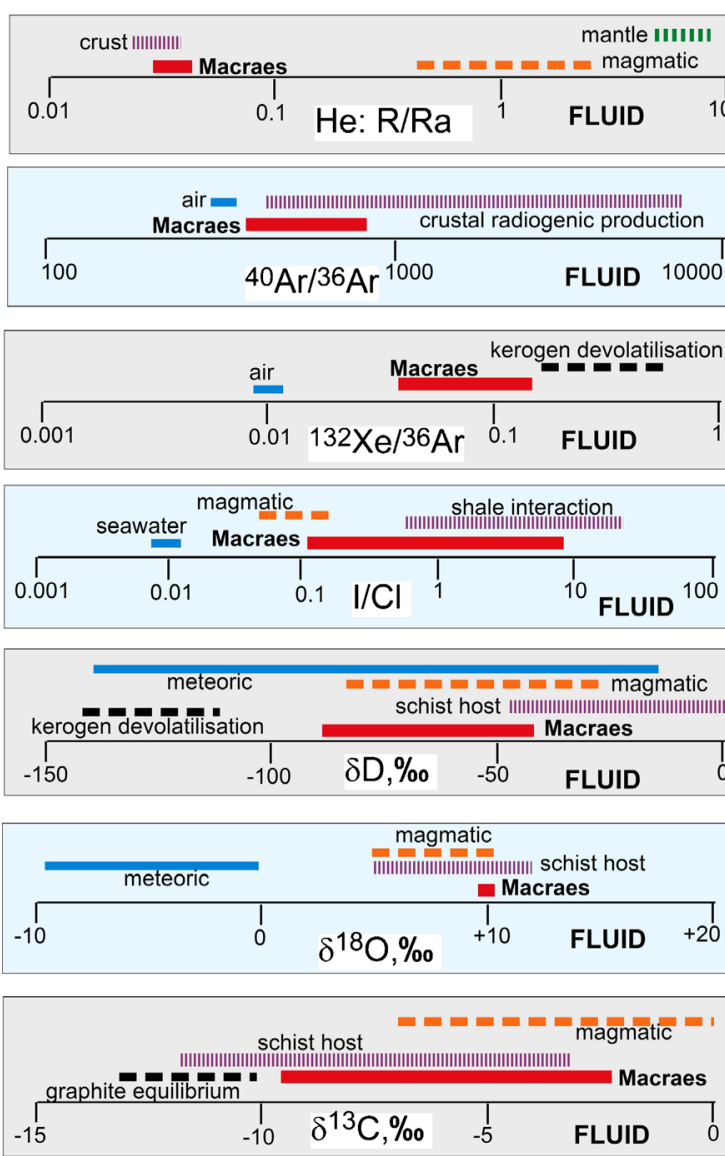

Fig. 8 Tracer data from Macraes deposit and related features, presented to compare key noble gas and halogen data (this study) with previously published fluid and rock data from the deposit and host rocks. Data are

\section{Conclusions}

The world-class Macraes orogenic gold deposit (>10 million ounce resource) formed in a compressional shear zone in the middle crust, near to the brittle-ductile transition, in the latter stages of metamorphism of the Mesozoic Otago Schist metamorphic belt. This metamorphic belt has no evidence for magmatic processes coeval with late Jurassic to Early Cretaceous hydrothermal gold mineralisation. Hence, the Macraes deposit is a well-defined amagmatic end member in a spectrum of orogenic gold deposit formation systems, some of which have magmatic and mantle-derived components in their mineralising fluids. All available geochemical tracers provide evidence for involvement of crustal fluids and crust-derived components in a metamorphogenic mineralising system that had little or no external contributions of fluids or metals. Rather, the fluids and metals were mobilised from the metasedimentary host rocks during metamorphism from pumpellyite-actinolite facies to amphibolite facies. There has been negligible contribution of geochemical components from minor intercalated metabasites to the mineralising system.

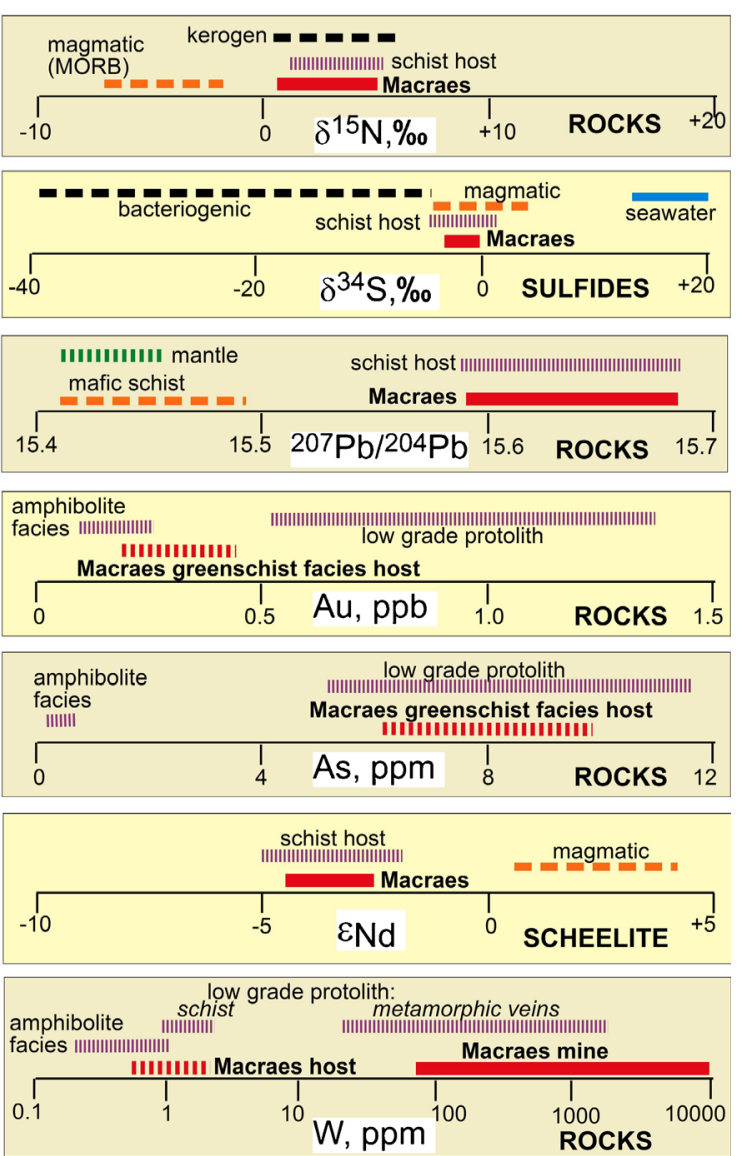

summarised from de Ronde et al. (2000), Pitcairn et al. (2005b, 2006, 2014), Craw et al. (2007) and references therein, and Farmer et al. (2012)

Noble gas and halogen ratios in fluid inclusions in Macraes mineralised rocks provide unequivocal evidence for primarily crustal processes during fluid generation, migration and mineralisation. Fluid inclusions extracted from three separate crush aliquots from a single Macraes sulphide sample have distinctively crustal $\mathrm{He}$ and $\mathrm{Ar}$ compositions, with aircorrected ${ }^{3} \mathrm{He} /{ }^{4} \mathrm{He}$ ratio of $\sim 0.03 \mathrm{Ra}$, indicating negligible contribution of mantle He. Relatively elevated xenon and iodine concentrations provide evidence for extensive geochemical interaction between fluids and the metasedimentary host rocks, particularly rocks with organic matter undergoing maturation. Fluid inclusion compositions are variable, suggesting either that mineralisation was driven by fluid that has had varying degrees of interaction with the metasedimentary host rocks, or that there has been mixing of two separate fluids, at least one of which was metamorphogenic in origin. However, it is not possible to discount some input of meteoric water into the mineralising fluid.

The Macraes deposit is the largest known mineralised system in the Otago Schist belt. Coeval Early Cretaceous tungsten-dominated orogenic deposits, and younger (middle Cretaceous) orogenic gold deposits formed at shallower levels 
than Macraes, in normal faults. Noble gas and halogen data suggest that their mineralising fluids had undergone less crustal fluid-rock interaction than did the Macraes system. Nevertheless, there is no evidence for magmatic input into formation of these deposits either. The late Mesozoic metamorphism and subsequent uplift and exhumation of the Otago Schist has generated two stages of orogenic hydrothermal activity, during which the mineralising systems resulted from mobilisation of crustal fluids and crust-derived metals and metalloids in the metasedimentary host rocks.

Acknowledgments Funding for this research was provided by University of Manchester, University of Otago and a NERC Ph.D. scholarship to the senior author. Dave Blagburn and Bev Clementson ably provided technical assistance for analytical work.

\section{References}

Ballentine CJ, Hall CM (1999) An inverse technique for calculating groundwater paleotemperature and other variables using noble gas concentrations in groundwater. Geochim Cosmochim Acta 63: 2315-2336

Ballentine CJ, Burgess R, Marty B (2002) Tracing fluid origin, transport and interaction in the crust. Rev Mineral Geochem 47:539-614

Battani A, Sarda P, Prinzhofer A (2000) Basin scale natural gas source, migration and trapping traced by noble gases and major elements: the Pakistan Indus basin. Earth Planet Sci Letters 181:229-249

Begbie MJ, Sibson RH (2006) Structural controls on the development of fault-hosted scheelite-gold mineralization in Glenorchy, northwest Otago: in Christie AB, Brathwaite RL eds. Geology and exploration of New Zealand mineral deposits: AusIMM Monog 25:291-298

Bohlke JK, Irwin JJ (1992a) Laser microprobe analyses of noble gas isotopes and halogens in fluid inclusions: analyses of microstandards and synthetic inclusions in quartz. Geochim Cosmochim Acta 56:187-201

Bohlke JK, Irwin JJ (1992b) Brine history indicated by argon, krypton, chlorine, bromine, and iodine analyses of fluid inclusions from the Mississippi Valley type lead-fluorite-barite deposits at Hansonburg, New Mexico. Earth Planet Sci Letters 110:51-66

Burnard PG, Polya DA (2004) Importance of mantle derived fluids during granite associated hydrothermal circulation: $\mathrm{He}$ and $\mathrm{Ar}$ isotopes of ore minerals from Panasqueira. Geochim Cosmochim Acta 68: $1607-1615$

Burnard PG, Hu RZ, Bi XW (1999) Mantle, crustal and atmospheric noble gases in Ailaoshan Gold deposits, Yunnan Province, China. Geochim Cosmochim Acta 63:1595-1604

Burrows DR, Wood PC, Spooner ETC (1986) Carbon isotope evidence for a magmatic origin for Archaean gold-quartz vein ore deposits. Nature 321:851-854

Craw D (2002) Geochemistry of late metamorphic hydrothermal alteration and graphitisation of host rock, Macraes gold mine, Otago Schist, New Zealand. Chem Geol 191:257-275

Craw D (2010) Delayed accumulation of placers during exhumation of orogenic gold in southern New Zealand. Ore Geology Reviews 37: 224-235

Craw D, Norris RJ (1991) Metamorphogenic Au-W veins and regional tectonics: mineralisation throughout the uplift history of the Haast Schist, New Zealand. NZ J Geol Geophys 34:373-383

Craw D, Windle SJ, Angus PV (1999) Gold mineralisation without quartz veins in a ductile-brittle shear zone, Macraes Mine, Otago Schist, New Zealand. Mineral Deposita 34:382-394
Craw D, Begbie M, MacKenzie D (2006) Structural controls on Tertiary orogenic gold mineralization during initiation of a mountain belt, New Zealand. Mineral Deposita 41:645-659

Craw D, MacKenzie DJ, Pitcairn IK, Teagle DAH, Norris RJ (2007) Geochemical signatures of mesothermal Au-mineralised late-metamorphic deformation zones, Otago Schist, New Zealand. Geochemistry: Explor Environ Analysis 7:225-232

de Ronde CEJ, Faure K, Bray CJ, Whitford FJ (2000) Round hill shear zone-hosted gold deposit, Macraes Flat, Otago, New Zealand: evidence of a magmatic ore fluid. Econ Geol 95:1025-1048

Fairmaid AM, Kendrick MA, Phillips D, Fu B (2011) The origin and evolution of mineralizing fluids in a sediment-hosted orogenic-gold deposit, Ballarat East, Southeastern Australia. Econ Geol 106:653666

Farmer L, Palin JM, Moore J, Teagle DAH, Stirling C (2012) The geochemistry and isotopic signature of scheelite from the Macraes orogenic gold deposit. Proceedings, AusIMM NZ Branch Conf, pp $145-153$

Goldfarb RJ, Baker T, Dube B, Groves DI, Hart CJ, Gosselin P (2005) Distribution, character and genesis of gold deposits in metamorphic terranes. In: Hedenquist JW, Thompson JFH, Goldfarb RJ, Richards JP (Eds.) Econ Geol 100th Anniv Vol, pp 407-450

Graupner T, Niedermann S, Kempe U, Klemd R, Bechtel A (2006) Origin of ore fluids in the Muruntau gold system: constraints from noble gas, carbon isotope and halogen data. Geochim Cosmochim Acta 70:5356-5370

Gray DR, Foster DA (2004) ${ }^{40} \mathrm{Ar} /{ }^{39} \mathrm{Ar}$ thermochronologic constraints on deformation, metamorphism and cooling/exhumation of a Mesozoic accretionary wedge. Otago Schist, New Zealand. Tectonophysics 385:181-210

Groves DI, Goldfarb RJ, Robert F, Hart CJR (2003) Gold deposits in metamorphic belts; overview of current understanding, outstanding problems, future research, and exploration significance. Econ Geol 98:1-29

Hagemann SG, Gebre-Mariam G, Groves DI (1994) Surface water influx in shallow level Archean lode gold deposits in Western Australia. Geology 22:1067-1070

Henne A, Craw D (2012) Synmetamorphic carbon mobility and graphite enrichment in metaturbidites as a precursor to orogenic gold mineralization, Otago Schist, New Zealand. Mineral Deposita 47:781797

Hoke L, Poreda R, Reay A, Weaver S (2000) The subcontinental mantle beneath southern New Zealand, characterised by helium isotopes in intraplate basalts and gas-rich springs. Geochim Cosmochim Acta 64:2489-2507

Hu RZ, Burnard PG, Bi XW, Zhou MF, Pen JT, Su WC, Wu KX (2004) Helium and argon isotope geochemistry of alkaline intrusionassociated gold and copper deposits along the Red RiverJinshajiang fault belt, SW China. Chem Geol 203:305-317

Hu RZ, Burnard PG, Bi XW, Zhou MF, Peng JT, Su WC, Zhao JH (2009) Mantle-derived gaseous components in ore-forming fluids of the Xiangshan uranium deposit, Jiangxi province, China: evidence from $\mathrm{He}, \mathrm{Ar}$ and $\mathrm{C}$ isotopes. Chem Geol 266:86-95

Hu RZ, Bi XW, Jian GH, Chen HW, Peng JT, Qi YQ, Wu LY, Wei WF (2012) Mantle-derived noble gases in ore-forming fluids of the granite-related Yaogangxian tungsten deposit, Southeastern China. Mineral Deposita 47:623-632

Jenkin GRT, Craw D, Fallick AE (1994) Stable isotopic and fluid inclusion evidence for meteoric fluid penetration into an active mountain belt; Alpine Schist, New Zealand. Jour Metamorphic Geol 12: 429 4443

Johnson LH, Burgess R, Turner G, Milledge HJ, Harris JW (2000) Noble gas and halogen geochemistry of mantle fluids; comparison of African and Canadian diamonds. Geochim Cosmochim Acta 64: $717-732$ 
Kendrick MA, Burgess R, Pattrick RAD, Turner G (2001) Fluid inclusion noble gas and halogen evidence on the origin of $\mathrm{Cu}$-porphyry mineralising fluids. Geochim Cosmochim Acta 65:2651-2668

Kendrick MA, Burgess R, Leach DL, Pattrick RAD (2002) Hydrothermal fluid origins in Mississippi Valley-type ore districts; combined noble gas $(\mathrm{He}, \mathrm{Ar}, \mathrm{Kr})$ and halogen $(\mathrm{Cl}, \mathrm{Br}, \mathrm{I})$ analysis of fluid inclusions from the Illinois-Kentucky fluorspar district, Viburnum Trend and Tri-State districts, midcontinent United States. Econ Geol 97:453469

Kendrick MA, Mark G, Phillips D (2007) Mid-crustal fluid mixing in a Proterozoic Fe-oxide-Cu-Au deposit. Ernest Henry, Australia: evidence from Ar, Kr, Xe, Cl, Br, and I. Earth Planet Sci Letters 256: 328-343

Kennedy BM, Torgersen T, van Soest MC (2002) Multiple atmospheric noble gas components in hydrocarbon reservoirs; a study of the Northwest Shelf, Delaware Basin, SE New Mexico. Geochim Cosmochim Acta 66:2807-2822

Large R, Thomas H, Craw D, Henne A, Henderson S (2012) Diagenetic pyrite as a source for metals in orogenic gold deposits, Otago Schist, New Zealand. NZ J Geol Geophys 55:137-149

Li X, Mao J, Wang C, Watanabe Y (2007) The Daduhe gold field at the eastern margin of the Tibetan Plateau: $\mathrm{He}, \mathrm{Ar}, \mathrm{S}, \mathrm{O}$, and $\mathrm{H}$ isotopic data and their metallogenic implications. Ore Geol Rev 30:244-256

Li J-W, Li Z-K, Zhou M-F, Chen L, Bi S-J, Deng X-D, Qiu H-N, Cohen B, Selby D, Zhao X-F (2012) The Early Cretaceous Yangzhaiyu lode gold deposit, North China Craton: a link between craton reactivation and gold veining. Econ Geol 107:43-79

MacKenzie DJ, Youngson JH, Craw D (2006) Taieri River mineralized vein swarm, East Otago. in Christie AB, Brathwaite RL (eds) Geology and exploration of New Zealand mineral deposits: AusIMM Monog 25:305-312

Mao J, Li Y, Goldfarb R, He Y, Zaw K (2003) Fluid inclusions and noble gas studies of the Dongping gold deposit, Heibei Province, China: a mantle connection for mineralization. Econ Geol 98:517-534

McKeag SA, Craw D (1989) Contrasting fluids in gold-bearing quartz vein systems formed progressively in a rising metamorphic belt; Otago Schist, New Zealand. Econ Geol 84:22-33

Menzies CD, Teagle DAH, Craw D, Cox SC, Boyce AJ, Barrie CD, Roberts S (2014) Incursion of meteoric waters into the ductile regime in an active orogen. Earth Planet Sci Letters 399:1-13

Moore J, Doyle S (2015) Resource definition in the world-class Macraes gold mine, New Zealand. Proceedings, PACRIM Congress, AusIMM Publ Series 2/2015, Carlton, Victoria, Australia, pp 557564

Mortensen JK, Craw D, MacKenzie DJ, Gabites JE, Ullrich T (2010) Age and origin of orogenic gold mineralisation in the Otago Schist belt, South Island, New Zealand: constraints from lead isotope and $40 \mathrm{Ar}$ / 39Ar dating studies. Econ Geol 105:777-793

Mortimer N (1993) Jurassic tectonic history of the Otago Schist, New Zealand. Tectonics 12:237-244

Mortimer N (2000) Metamorphic discontinuities in orogenic belts: example of garnet-biotite-albite zone in the Otago Schist. New Zealand. Int J Earth Sci 89:295-306

Muramatsu Y, Wedepohl KH (1998) The distribution of iodine in the earth's crust. Chem Geol 147:201-216

Muramatsu Y, Doi T, Tomaru H, Fehn U, Takeuchi R, Matsumoto R (2007) Halogen concentrations in pore waters and sediments of the
Nankai trough. Japan: implications for the origin of gas hydrates. Appl Geochem 22:534-556

Nesbitt BE, Muehlenbachs K (1995) Geochemical studies of the origins and effects of synorogenic crustal fluids in the southern Omineca belt of British Columbia, Canada. GSA Bull 107:1033-1050

Ozima M, Podosek FA (2002) Noble gas geochemistry. Cambridge University Press, Cambridge, $\mathbf{2 8 6}$ p

Paterson CJ (1986) Controls on gold and tungsten mineralization in metamorphic-hydrothermal systems. Otago, New Zealand. Geol Assoc Canada Spec Paper 32:25-39

Petrie BS, Craw D, Ryan CG (2005) Geological controls on refractory ore in an orogenic gold deposit, Macraes mine, New Zealand. Mineral Deposita 40:45-58

Pitcairn IK, Roberts S, Teagle DAH, Craw D (2005a) Detecting hydrothermal graphite deposition during metamorphism and gold mineralisation. J Geol Soc, London 162:429-432

Pitcairn IK, Teagle DAH, Kerrich R, Craw D, Brewer TS (2005b) The behaviour of nitrogen and nitrogen isotopes during metamorphism and mineralisation: evidence from the Otago and Alpine Schists, New Zealand. Earth Planet Sci Letters 233:229-246

Pitcairn IK, Teagle DAH, Craw D, Olivo GR, Kerrich R, Brewer TS (2006) Sources of metals and fluids in orogenic gold deposits: insights from the Otago and Alpine Schists, New Zealand. Econ Geol 101:1525-1546

Pitcairn IK, Craw D, Teagle DAH (2014) The gold conveyor belt: largescale gold mobility in an active orogen. Ore Geol Rev 62:129-142

Stuart FM, Burnard PG, Taylor RP, Turner G (1995) Resolving mantle and crustal contributions to ancient hydrothermal fluids: He-Ar isotopes in fluid inclusions from Dae Hwa W-Mo mineralization, South Korea. Geochim Cosmochim Acta 59:4663-4673

Sumino H, Nagao K, Notsu K (2001) Highly sensitive and precise measurement of helium isotopes using a mass spectrometer with double collector system. J Mass Spectrom Soc Japan 49:61-68

Sun X, Zhang Y, Xiong D, Sun W, Shi G, Zhai W, Wang S (2009) Crust and mantle contributions to gold-forming process at the Daping deposit, Ailaoshan gold belt, Yunnan, China. Ore Geol Rev 36: 235-249

Torgersen T, Kennedy BM (1999) Air-Xe enrichments in Elk Hills oil field gases: role of water in migration and storage. Earth Planet Sci Letters 167:239-253

Tulloch AJ, Ramezani J, Mortimer N, Mortensen J, van den Bogaard P, Maas R (2009) Cretaceous felsic volcanism in New Zealand and Lord Howe Rise (Zealandia) as a precursor to final Gondwana breakup. Geol Soc London Special Paper 321:89-118

Turnbull IM, Allibone AH, Jongens R (2010) Geology of the Fiordland area. Institute of Geological and Nuclear Sciences 1:250 000 Geological Map 17. Lower Hutt, NZ

Turner G, Burnard P, Ford JL, Gilmour JD, Lyon IC, Stuart FM (1993) Tracing fluid sources and interactions. Phil TransRoyal Soc London Series A, Math Phys Eng Sci 344:127-140

Williams GJ 1974. Economic geology of New Zealand. AusIMM Monog

Zhou Z, Ballentine CJ, Kipfer R, Schoell M, Thibodeaux S (2005) Noble gas tracing of groundwater/coalbed methane interaction in the San Juan Basin. USA Geochim Cosmochim Acta 69:5413-5428 